\title{
ENVIRONMENTALLY FRIENDLY WOOD COMPOSITE FABRICATED FROM RUBBERWOOD USING CITRIC ACID ESTERIFIED OIL PALM STARCH
}

\author{
MOHD HAZIM MOHAMAD AMINI, ROKIAH HASHIM, ${ }^{* *}$ NURUL SYUHADA SULAIMAN, ${ }^{* *}$ \\ OTHMAN SULAIMAN ${ }^{* *}$ and AZWAN MAT LAZIM*** \\ *Faculty of Bio-Engineering and Technology, Universiti Malaysia Kelantan, \\ 17600 Jeli, Kelantan, Malaysia \\ ** Division of Bioresources, Paper and Coatings Technology, School of Industrial Technology, Universiti \\ Sains Malaysia, 11800 Penang, Malaysia \\ ${ }^{* * *}$ Faculty of Science and Technology, Universiti Kebangsaan Malaysia, \\ 43600 UKM Bangi, Selangor, Malaysia \\ ๑ Corresponding author: M. H. M. Amini, hazimamini@gmail.com
}

Received December 3, 2017

Oil palm trees older than 25 years of age are usually cut down because of low productivity and the resulting biomass is left to degrade naturally. Unfortunately, the disposal of this biomass becomes a major issue in many plantations, as it requires additional costs. Considering the high starch content of oil palm trunks, it is essential to find a potential utilisation for this biomass. The main objective of this study was to evaluate some of the properties of experimentally manufactured particleboard panels made from rubberwood (Hevea brasiliensis) using oil palm starch as a binder. The starch extracted from oil palm trunk was esterified using citric acid before being used as an organic-based wood binder. Three types of panels, namely, one bound with citric acid modified oil palm starch (CAMOPS), another using a combination of citric acid modified oil palm starch and $2 \%$ urea formaldehyde (CAMOPSUF), and finally, the third glued with urea formaldehyde resin (control), were manufactured in the study. Panels of $210 \mathrm{~mm} \times 210 \mathrm{~mm} \times 50 \mathrm{~mm}$ dimensions were made at three target density levels. The results showed that the thickness swelling of CAMOPSUF wood composites improved up to $79.37 \%$. Furthermore, at $0.70 \mathrm{gcm}^{-3}$ density level, all the wood composites met the mechanical strength standard, as proposed by the Japanese Industrial Standards. The wood composite prepared using modified oil palm starch binder has high potential to be commercialized, besides offering a way to improve waste disposal management on oil palm plantations.

Keywords: composite, oil palm, starch, wood, binder

\section{INTRODUCTION}

Indonesia and Malaysia are the two biggest palm oil producers in the world. Statistics indicates that 45.3 million tons of palm oil are produced every year from plantations that accumulate millions of hectares. ${ }^{1}$ In Malaysia, many initiatives have been made to reduce the disposal problems by utilizing oil palm biomass for manufacturing biocomposites, such as medium density fibreboard and plywood, or for energy generation as a burning agent to produce electricity. ${ }^{2,3}$ Although efforts have been made to utilize oil palm biomass, unfortunately, only $10 \%$ from its abundance is fully exploited. Direct burning of oil palm trunks is a conventional approach to generate energy. However, burning leads to the release of gases, such as $\mathrm{CO}, \mathrm{CO}_{2}$ and organic compounds, such as organic acids or inorganic matter. These chemical compounds and particularly the inorganic matter lowers the air quality and consequently, affects human health. ${ }^{4}$

Oil palm trunk contains approximately $7.15 \%$ starch, while more than $55.5 \%$ of its parenchyma is occupied by starch. ${ }^{5,6}$ Therefore, starch can be extracted from the waste for more valuable applications. One of its potential uses is as an environmentally friendly binder in the manufacture of wood composites. Current practices utilise formaldehyde-based binders, such 
as urea formaldehyde, melamine formaldehyde and phenol formaldehyde based resins, which are notably known as causing human cancerous cell activation. ${ }^{7}$ Thus, due to social awareness, formaldehyde-based adhesives are now less desired in the manufacture of wood composites in European countries.

Alternatively, studies have been conducted on using starch as a green adhesive for wood composites. As examples, epichlorohydrin modified oil palm starch, ${ }^{8}$ citric acid modified pea starch, ${ }^{9}$ epichlorohydrin modified rice starch, ${ }^{10}$ corn starch-tannin combination 11 and glutardialdehyde modified corn $\operatorname{starch}^{12}$ are among the binders that have been extensively used to formulate wood composites. Despite its ability as a green binder, starch is also consumed as a staple food and is widely used as a food ingredient. Economically, the usage of a foodbased material for non-edible products consequently creates another conflict, which might result in a price hike. However, starch extracted from oil palm trunk is generally not suitable for food, considering its non-hygienic source. Therefore, non-edible starch from oil palm trunk is a good candidate the production of goods, without any issues.

One of the major drawbacks that limit the further applications of starch is its weak resistance to moisture. ${ }^{13}$ Using solely native starch as a binder for wood composites will make them less durable when exposed to a high humidity environment. The hydroxyl groups in the polysaccharide chains tend to interact with water, thus, reducing the strength of wood composites over time. Starch modifications are crucial to overcome this problem. In this study, starch extracted from oil palm trunk was chemically modified using citric acid to be used as a binder in wood-based composites. The chemically modified oil palm starch was mixed with rubberwood particles before hot-pressing to form composites. The prepared wood composites were subjected to physical, mechanical and fungal resistance testing. The findings of this work will broaden the potential use of oil palm starch as an alternative material for wood composites.

\section{EXPERIMENTAL}

\section{Sample collection and preparation}

Oil palm trunks from unproductive trees were collected from local oil palm plantations located in Kedah, Malaysia. Freshly cut oil palm trunks were reduced in size, using a mechanical chipper machine.
The moisture content was measured using the oven drying method. ${ }^{14}$ Powdered citric acid of $99.5 \%$ purity was obtained from Sigma-Aldrich, and urea formaldehyde was acquired from Momento Specialty Chemical, Prai, Penang, Malaysia.

\section{Extraction of oil palm starch}

About $100 \mathrm{~g}$ of chipped oil palm trunks were soaked in $1000 \mathrm{~mL}$ sodium metabisulphite with $0.5 \%$ concentration. The mixtures were left overnight before being transferred into a nylon cloth and squeezed to extract the starch. The liquid obtained was filtered to remove small particles and left to settle for $60 \mathrm{~min}$. The supernatant of the starch suspensions was poured out before adding distilled water to the residue. The final mixture was centrifuged at $4000 \mathrm{rpm}$ for $20 \mathrm{~min}$ using a Beckman Coulter Allegra X-15R to separate the starch from the suspension. The final residue was washed twice with $50 \mathrm{~mL}$ of acetone. It was then dried in an oven at $45 \pm 5{ }^{\circ} \mathrm{C}$ overnight and finally stored for further analyses and experiments. In this study, three types of binders were used: citric acid modified oil palm starch (CAMOPS), citric acid modified oil palm starch with $2 \%$ urea formaldehyde (CASMOPSUF) and urea formaldehyde (UF) as a control sample.

\section{Preparation of binder}

Esterification of starch using citric acid was carried out using the method reported by Reddy and Yang. ${ }^{15}$ The extracted oil palm starch was mixed with $250 \mathrm{~mL}$ of distilled water and continuously stirred in a water bath at $50{ }^{\circ} \mathrm{C}$. About $10 \mathrm{~g}$ of citric acid was added to the starch solution, followed by the addition of sodium hypophosphite as a catalyst at $50 \% \mathrm{w} / \mathrm{w}$ on the weight of citric acid used. The temperature of the water bath was raised to $90{ }^{\circ} \mathrm{C}$ with stirring and continued until resinification was attained. The binder prepared was the oil palm starch modified with citric acid in a thick liquid form. Similarly to other conventional binders, such as urea formaldehyde, the binder was mixed with the fibers in the next step, before curing to form wood composites.

\section{Wood composite making}

Panels were made using a stainless steel mould of $210 \mathrm{~mm} \times 210 \mathrm{~mm} \times 5 \mathrm{~mm}$ at target density levels of $0.60 \mathrm{gcm}^{-3}, 0.70 \mathrm{gcm}^{-3}$ and $0.80 \mathrm{gcm}^{-3}$. Non-treated rubberwood particles, obtained from Heveaboard Malaysia Company, were mixed with $13 \%$ modified oil palm starch and $2 \%$ urea formaldehyde before they were cold-pressed to form a mat. The prepared mat was then heat-pressed to cure under a pressure of 5 Mpa at $165{ }^{\circ} \mathrm{C}$ for $20 \mathrm{~min}$. The panels were cooled down, sandwiched between steel plates to ensure a flat shape was obtained. The panels were then conditioned in a conditioning room at $25{ }^{\circ} \mathrm{C}$ with a relative humidity of $65 \%$ for two weeks before being evaluated as to their properties. 


\section{Characterization of wood composite}

Fourier transform infrared (FT-IR) spectroscopy was carried out using a Thermo Scientific Nicolet 6700 FT-IR spectrometer to determine the differences of functional groups. Pellets of $100 \mathrm{~g}$ of potassium bromide $(\mathrm{KBr})$ were prepared and then analyzed at wavenumbers between $4000 \mathrm{~cm}^{-1}$ and $470 \mathrm{~cm}^{-1}$, as previously reported. $^{16,17}$ A Shimadzu TGA-50 was used for thermogravimetry analysis. About $10 \mathrm{mg}$ of powdered sample was heated from 30 to $700{ }^{\circ} \mathrm{C}$ at a heating rate of $10{ }^{\circ} \mathrm{C} / \mathrm{min}$. The nitrogen flow was maintained at $20 \mathrm{~mL} / \mathrm{min}$ to create an inert atmosphere. Differential scanning calorimetry was performed from $20{ }^{\circ} \mathrm{C}$ to $120{ }^{\circ} \mathrm{C}$, at a heating rate of $10{ }^{\circ} \mathrm{C} / \mathrm{min}$, using a Perkin Elmer DSC 4000 differential scanning calorimeter. X-ray diffraction patterns were generated using a Shimadzu XRD-6000. The samples were analyzed for their crystallinity by step scan measurements, using $\mathrm{X}$-rays $(\mathrm{Cu}-\mathrm{Ka})$ at $40 \mathrm{kV}$ and 40 $\mathrm{mA}$. Scanning of $2 \theta$ was done from $10.0^{\circ}$ to $40.0^{\circ}$ with scanning speeds set at $0.02 \% \mathrm{~min}$ and $2 \% \mathrm{~min} .{ }^{18}$ The crystallinity index (C Ir) was determined by Equation 1:

$\operatorname{CIr}(\%)=\frac{\left(h_{\mathrm{aco}}-\operatorname{tam}_{\operatorname{man}}\right)}{t_{\text {hoo }}} \times 100$

where $I_{200}$ is the peak intensity corresponding to the crystalline fraction and $\mathrm{I}_{\mathrm{am}}$ is the peak intensity of the amorphous fraction.

\section{Testing of wood composites}

\section{Physical and mechanical properties}

Moisture content analysis was performed using the oven drying method. Water absorption and thickness swelling after immersion in water and exposure to different relative humidity $(35 \%, 55 \%, 75 \%$ and $95 \%)$ followed the Japanese Industrial Standards, ${ }^{19}$ using sample dimensions of $5 \mathrm{~cm} \times 5 \mathrm{~cm} \times 0.5 \mathrm{~cm}$. The flexural and internal bonding strength was also analyzed following the same standard, using an INSTRON tensile strength tester machine.

\section{Fungal resistance}

Fungal resistance testing of the wood composites was carried out according to the British Standard BS 1982-2. ${ }^{20}$ Trametes versicolor, Formitopsis palustris, Schizophyllum commune and Pycnoporus sangineus were cultured in incubators. All the fungal colonies used for testing in this study were obtained from the School of Biology, Universiti Sains Malaysia, Penang, Malaysia. A sample of $25 \mathrm{~mm}$ x $25 \mathrm{~mm}$ was laid on sterilized soil inside a clean bottle. Agar plugs from the edge of actively growing colonies were inoculated onto the samples before being incubated for six months. The final weight was taken, and the degree of fungal attack was calculated using Equation 2:

Degree of fungal attack, $\%=\frac{m_{i}-m_{f}}{m_{l}} \times 100$

where $\mathrm{m}_{\mathrm{i}}$ is the initial weight of the conditioned specimens before fungal exposure and $o_{f}$ are the final weight of conditioned specimens after fungal exposure.

\section{RESULTS AND DISCUSSION Characterization of wood composites Fourier transform infrared (FT-IR) analysis}

The FT-IR spectra obtained for the CAMOPS wood composite (A), the CAMOPSUF wood composite (B) and the urea formaldehyde wood composite (C) are shown in Figure 1. The wood composite made with citric acid modified oil palm starch showed the existence of hydroxyl groups $(\mathrm{O}-\mathrm{H})$ at the wavenumbers $3385.29 \mathrm{~cm}^{-1}, 2922.46$ $\mathrm{cm}^{-1}$ and $1331.01 \mathrm{~cm}^{-1}$. The characteristic of starch modified with citric acid, which is the ester group, is present at the peak numbers of 1737.27 $\mathrm{cm}^{-1}, 1733.84 \mathrm{~cm}^{-1}$ and $1645.34 \mathrm{~cm}^{-1}$. Umemura et $a l .^{21}$ found that citric acid, which reacted with wood components, obviously showed the existence of hydroxyl groups where ester bonds were formed. These linkages increased cohesion, thus enhanced the physical and mechanical properties of the wood composite. Meanwhile, the stretching at $1733.84 \mathrm{~cm}^{-1}$ refers to the anhydride group created after citric acid was heated. The suggested mechanism of reaction for citric acid with starch is shown in Figure 2.

As for the CAMOPSUF wood composite, the peaks at $3378.51 \mathrm{~cm}^{-1}, 2922.17 \mathrm{~cm}^{-1}, 1374.47 \mathrm{~cm}$ and $1331.91 \mathrm{~cm}^{-1}$ indicate the presence of hydroxyl groups. The crosslinking of the citric acid modified starch is indicated by the peak at $1736.42 \mathrm{~cm}^{-1}$, which refers to the ester group. The existence of urea formaldehyde resin indicated by $\mathrm{N}-\mathrm{H}$ vibrations can be remarked at $3378.51 \mathrm{~cm}^{-1}$, $1650.46 \mathrm{~cm}^{-1}, 1596.48 \mathrm{~cm}^{-1}$ and $1506.95 \mathrm{~cm}^{-1}$. The absorbance at $1035.83 \mathrm{~cm}^{-1}$ indicates that a methylene linkage was formed by the urea formaldehyde in the curing process, which contributes to the performance of the wood composite. $^{22}$ All of the wood composite samples showed peaks around $1330 \mathrm{~cm}^{-1}$, which indicated the existence of $\mathrm{C}-\mathrm{N}$ vibration, contributing the antioxidant activity, as reported by Azman et al. ${ }^{23}$ 


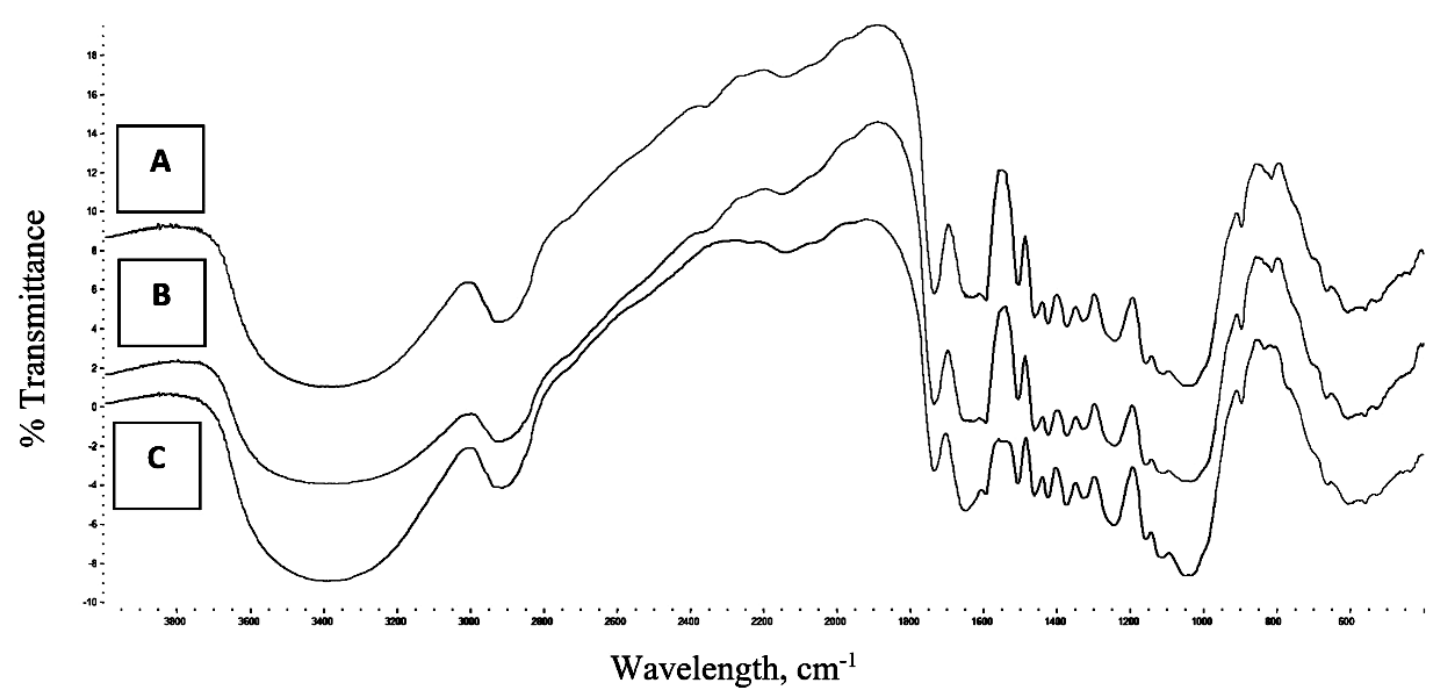

Figure 1: FT-IR spectra for CAMOPS (A), CAMOPSUF (B) and urea formaldehyde (C) wood composites, respectively

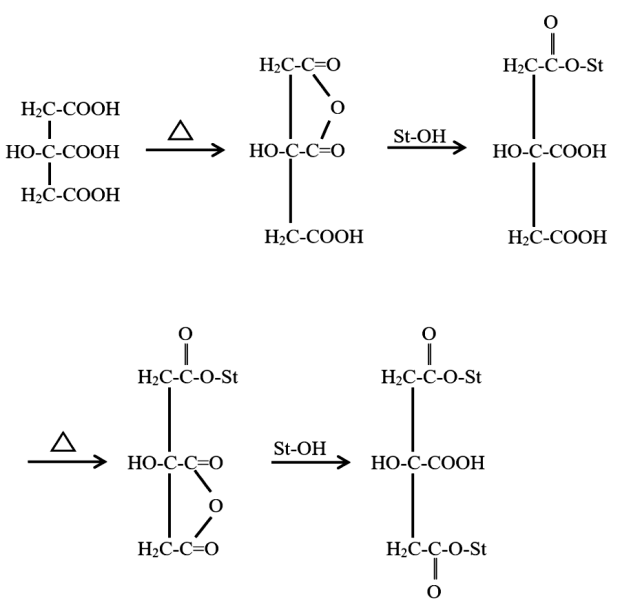

Figure 2: Reaction of citric acid with starch

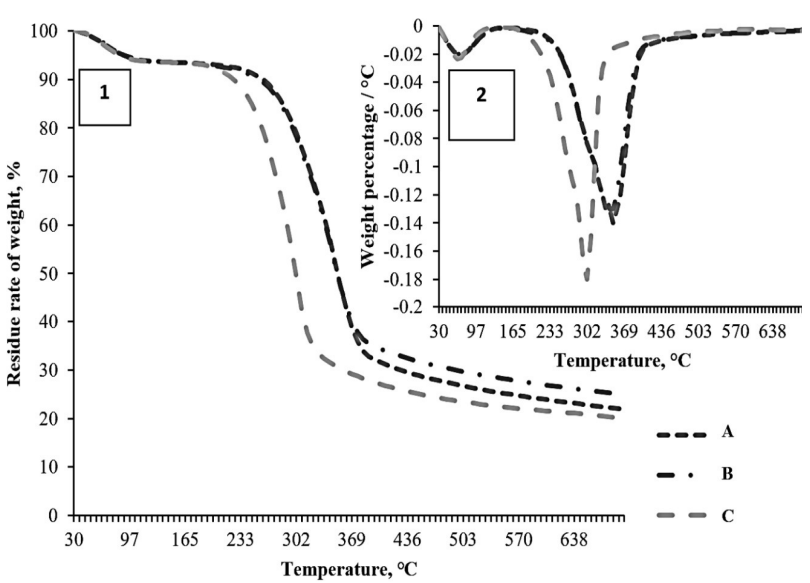

Figure 3: TG (1) and DTG (2) curves for CAMOPS (A), CAMOPSUF (B) and urea formaldehyde (C) wood composites, respectively

$0.14 \% / \mathrm{min}$. Meanwhile, the CAMOPSUF wood composite and the urea formaldehyde wood composite demonstrated weight losses of $68.07 \%$ and $68.59 \%$, respectively. Finally, at $700{ }^{\circ} \mathrm{C}$, the remaining residue of the wood composites CAMOPS, CAMOPSUF and urea formaldehyde was recorded as $21.97 \% 19.95 \%$ and $20.08 \%$, respectively. Thus, from the results obtained, it can be concluded that the addition of urea formaldehyde to the binder formulation produced little influence on the thermal stability of the wood composites.

The DSC is essential to measure the increment or decrement of the glass transition temperature of wood composites made using modified starch, as it reflects the quality of chemical bonding. ${ }^{24}$ 
Figure 4 illustrates the DSC curves for the CAMOPS wood composite, the CAMOPSUF wood composite and the urea formaldehyde wood composite, revealing melting peaks of $88{ }^{\circ} \mathrm{C}, 83$ ${ }^{\circ} \mathrm{C}$ and $95{ }^{\circ} \mathrm{C}$, respectively. Melting temperatures were not affected by the choice of the binder, as indicated by the DSC curves. The presence of urea formaldehyde lowered the energy absorbed, as the CAMOPS wood composite exhibited the highest energy absorption of $6.60 \mathrm{~mW}$, the CAMOPSUF wood composite - of $6.30 \mathrm{~mW}$ and the urea formaldehyde wood composite - of 3.62 $\mathrm{mW}$. Similar results were reported by Osemeahon et al., ${ }^{26}$ who remarked that the increment in the starch content in the starch/urea formaldehyde blending formulation reduced the melting point.

\section{$X$-ray diffraction analysis}

The crystallinity index was determined to have the values of $21.43 \%, 21.95 \%$ and $14.93 \%$ for the CAMOPS, CAMOPSUF and urea formaldehyde wood composites, respectively. Figure 5 displays the X-ray diffraction (XRD) patterns for the prepared composites. The addition of $2 \%$ urea formaldehyde slightly changed the crystallinity of the wood composite. Consequently, the particleboard prepared using urea formaldehyde as binder showed higher amorphous structure, which contributed to its higher mechanical strength, but lower thermal stability, as discussed in the thermal analysis above. ${ }^{27,28}$ When lignocellulose materials are in contact with moisture, the amorphous region will be the first to absorb moisture. The citric acid will esterify the hydroxyl groups to form ester linkages. Ester

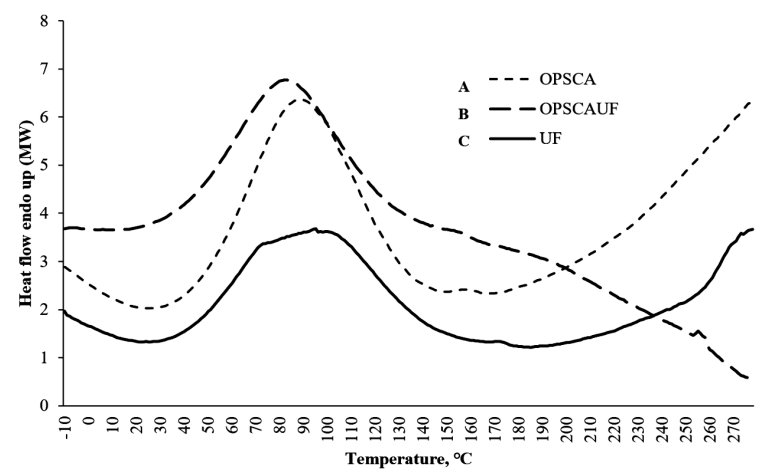

Figure 4: Differential scanning calorimetry curves for CAMOPS (A), CAMOPSUF (B) and urea formaldehyde (C) wood composites, respectively linkages will rearrange the molecule chains in the amorphous region, thus increasing the crystallinity of the cellulose. ${ }^{29}$ Therefore, the CAMOPS and CAMOPSUF wood composites have lower mechanical strength, compared to that of the urea formaldehyde wood composite, as discussed in the analysis of mechanical properties below.

\section{Physical properties}

Measured density and dimensional stability after water immersion

Statistical analysis was carried out to find statistically significant differences related to different density of the wood composites and the data are presented in Table 1. Table 1 also shows the thickness swelling and water absorption of the particleboards after different periods of immersion into water, of 2 hours and 24 hours. Water absorption leads to thickness swelling in wood composites. Ghofrani et al. ${ }^{30}$ suggested that the water absorption of composites is related to the hydrogen bonding of water molecules to the free hydroxyl groups present in the cellulosic materials, as well as to the diffusion of water molecules into the filler-matrix interfaces. The results indicate that a longer immersion period leads to increased water absorption. The moisture penetrates into the pores and breaks the hydrogen bonding between the fibers, resulting in the swelling of the composites. ${ }^{10}$ Thickness swelling also occurred because of the 'spring back' effect, as the residual stress created by hot-pressing was released, making the fibers tend to move apart from each other. ${ }^{31}$

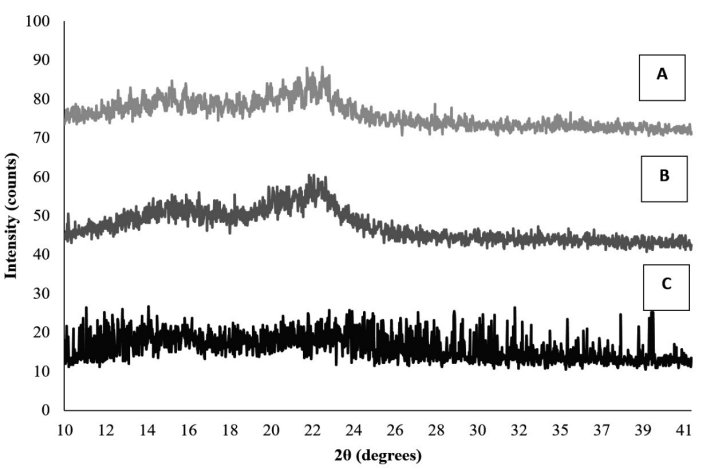

Figure 5: X-ray diffraction patterns for CAMOPS (A), CAMOPSUF (B) and urea formaldehyde (C) wood composites, respectively 
MOHD HAZIM MOHAMAD AMINI et al.

Table 1

Density, moisture content, thickness swelling and water absorption of the manufactured wood composites

\begin{tabular}{|c|c|c|c|c|c|c|c|}
\hline Panel type & $\begin{array}{l}\text { Target density } \\
\left(\mathrm{g} / \mathrm{cm}^{3}\right)\end{array}$ & $\begin{array}{c}\text { Moisture } \\
\text { content }(\%)\end{array}$ & $\begin{array}{c}\text { Measured } \\
\text { density }\left(\mathrm{g} / \mathrm{cm}^{3}\right)\end{array}$ & $\begin{array}{c}\text { Thickness } \\
\text { swelling }(\%, 2 \mathrm{~h})\end{array}$ & $\begin{array}{c}\text { Thickness } \\
\text { swelling }(\%, 24 \mathrm{~h})\end{array}$ & $\begin{array}{c}\text { Water absorption } \\
(\%, 2 \mathrm{~h})\end{array}$ & $\begin{array}{c}\text { Water absorption } \\
(\%, 24 \mathrm{~h})\end{array}$ \\
\hline \multirow{3}{*}{ CAMOPS } & 0.60 & $6.10 \pm 0.23 a$ & $0.57 \pm 0.05 a$ & $60.56 \pm 11.32 \mathrm{a}$ & $76.98 \pm 14.96 \mathrm{a}$ & $140.38 \pm 6.99 a$ & $172.10 \pm 7.34 \mathrm{a}$ \\
\hline & 0.70 & $7.93 \pm 0.31 b$ & $0.66 \pm 0.06 b$ & $74.72 \pm 16.97 b$ & $84.99 \pm 6.82 \mathrm{a}$ & $134.92 \pm 4.63 \mathrm{ab}$ & $166.23 \pm 5.21 \mathrm{a}$ \\
\hline & 0.80 & $6.34 \pm 0.32 c$ & $0.75 \pm 0.15 c$ & $83.69 \pm 16.04 b$ & $100.96 \pm 11.05 b$ & $131.40 \pm 9.65 b$ & $166.27 \pm 14.46 \mathrm{a}$ \\
\hline \multirow{3}{*}{ CAMOPSUF } & 0.60 & $4.74 \pm 0.09 a$ & $0.57 \pm 0.07 a$ & $59.74 \pm 14.03 a$ & $69.60 \pm 13.63 a$ & $144.74 \pm 6.86 a$ & $157.78 \pm 3.47 \mathrm{a}$ \\
\hline & 0.70 & $4.69 \pm 0.05 a$ & $0.67 \pm 0.08 b$ & $65.92 \pm 9.90 \mathrm{a}$ & $75.37 \pm 9.28 \mathrm{a}$ & $130.15 \pm 10.98 b$ & $152.40 \pm 8.19 \mathrm{a}$ \\
\hline & 0.80 & $7.50 \pm 0.21 b$ & $0.75 \pm 0.19 \mathrm{c}$ & $54.27 \pm 12.87 \mathrm{ab}$ & $79.37 \pm 16.45 a$ & $124.98 \pm 8.32 b c$ & $152.17 \pm 11.89 \mathrm{a}$ \\
\hline \multirow{3}{*}{$\begin{array}{l}\text { Urea } \\
\text { formaldehyde }\end{array}$} & 0.60 & $4.59 \pm 0.11 \mathrm{a}$ & $0.56 \pm 0.03 a$ & $16.54 \pm 3.64 a$ & $38.59 \pm 6.99 a$ & $48.88 \pm 9.37 \mathrm{a}$ & $111.58 \pm 21.69 a$ \\
\hline & 0.70 & $4.50 \pm 0.01 \mathrm{a}$ & $0.68 \pm 0.04 b$ & $19.29 \pm 2.61 b$ & $46.72 \pm 5.81 b$ & $44.94 \pm 4.40 \mathrm{ab}$ & $97.46 \pm 6.36 \mathrm{a}$ \\
\hline & 0.80 & $4.07 \pm 0.10 \mathrm{~b}$ & $0.78 \pm 0.13 c$ & $18.84 \pm 2.59 \mathrm{ab}$ & $48.52 \pm 6.43 b$ & $41.67 \pm 11.70 \mathrm{~b}$ & $100.33 \pm 23.52 \mathrm{a}$ \\
\hline
\end{tabular}

*different letter in the same column and for the same type of binder shows significant difference at a value of 0.05

Table 2

Bending and internal bonding strength of CAMOPS, CAMOPSUF and urea formaldehyde wood composites in comparison with other reported results

\begin{tabular}{|c|c|c|c|c|c|}
\hline Panel type & $\begin{array}{l}\text { Target density } \\
\left(\mathrm{g} / \mathrm{cm}^{3}\right)\end{array}$ & $\begin{array}{l}\text { MOR of bending test } \\
\left(\mathrm{N} / \mathrm{mm}^{2}\right)\end{array}$ & $\begin{array}{l}\text { MOE of bending test } \\
\left(\mathrm{N} / \mathrm{mm}^{2}\right)\end{array}$ & $\begin{array}{c}\text { Internal bonding } \\
\left(\mathrm{N} / \mathrm{mm}^{2}\right)\end{array}$ & Reference \\
\hline \multirow{3}{*}{ CAMOPS } & 0.60 & $6.38 \pm 1.11 \mathrm{a}$ & $1521.09 \pm 370.93 \mathrm{a}$ & $0.36 \pm 0.12 \mathrm{a}$ & This work \\
\hline & 0.70 & $8.65 \pm 2.58 b$ & $2311.91 \pm 423.77 \mathrm{a}$ & $0.42 \pm 0.12 \mathrm{a}$ & This work \\
\hline & 0.80 & $12.35 \pm 1.64 \mathrm{c}$ & $3046.80 \pm 343.19 b$ & $0.55 \pm 0.12 b$ & This work \\
\hline \multirow{3}{*}{ CAMOPSUF } & 0.60 & $8.67 \pm 2.59 a$ & $2483.23 \pm 587.30 \mathrm{a}$ & $0.42 \pm 0.13 a$ & This work \\
\hline & 0.70 & $10.08 \pm 2.40 \mathrm{a}$ & $2831.26 \pm 253.54 a$ & $0.50 \pm 0.06 \mathrm{a}$ & This work \\
\hline & 0.80 & $16.27 \pm 5.57 \mathrm{~b}$ & $3784.99 \pm 857.30 \mathrm{~b}$ & $0.66 \pm 0.07 b$ & This work \\
\hline \multirow{3}{*}{ Urea formaldehyde } & 0.60 & $14.83 \pm 5.25 a$ & $2599.94 \pm 683.36 a$ & $0.94 \pm 0.31 \mathrm{a}$ & This work \\
\hline & 0.70 & $19.66 \pm 3.41 \mathrm{ab}$ & $3543.45 \pm 576.45 b$ & $0.98 \pm 0.26 \mathrm{a}$ & This work \\
\hline & 0.80 & $25.54 \pm 5.67 \mathrm{~b}$ & $5039.47 \pm 739.94 \mathrm{c}$ & $1.14 \pm 0.16 \mathrm{a}$ & This work \\
\hline Eastern red cedar (Juniperus virginiana L.) & 0.70 & $11.17(1.69)$ & $2241.92 \pm 225.53$ & $0.57 \pm 0.07$ & 30 \\
\hline with glutardialdehyde modified starch & 0.80 & $12.14(0.45)$ & $2344.32 \pm 122.35$ & $0.62 \pm 0.06$ & 30 \\
\hline Corncob with Fevicol resin & 0.60 & $1.50 \pm 0.02$ & $61.82 \pm 10.09$ & - & 29 \\
\hline Corn starch/urea formaldehyde blend & 0.68 & $18.6 \pm 0.8$ & $3171 \pm 72$ & $0.57 \pm 0.02$ & 31 \\
\hline Epichlorohydrin modified oil palm starch & 0.80 & $11.86 \pm 2.71$ & $3137.92 \pm 332.73$ & $0.21 \pm 0.09$ & 8 \\
\hline
\end{tabular}

*different letter in the same column and for the same type of binder shows significant difference at a value of 0.051 
After 24 hours of immersion in water, all the samples showed higher thickness swelling with an increment in density. Higher density stands for higher mass in the same volume, which contributes to a higher compaction ratio and residual stress. Higher residual stress results in higher thickness swelling, as more stress is released. The addition of urea formaldehyde produced more stable wood composites, as the thickness swelling after 24 hours of water immersion was reduced from $100.96 \%$ for CAMOPS to $79.37 \%$ for CAMOPSUF at 0.80 $\mathrm{g} / \mathrm{cm}^{3}$ density. The wood composite bound using only urea formaldehyde showed the lowest water absorption of $48.52 \%$.

\section{Effect of relative humidity on dimensional stability}

Table 1 shows the thickness swelling for the CAMOPS, CAMOPSUF and urea formaldehyde wood composites at different relative humidity. At a relative humidity of $35 \%$, shrinkage was observed for all the samples. Then, at a relative humidity under $75 \%$, the difference in thickness swelling between the samples was not significant. However, at a relative humidity of $95 \%$, the addition of urea formaldehyde in the wood composite was noted to decrease the thickness swelling from $24.50 \%$ to $14.05 \%$ and to $11.54 \%$ for CAMOPS, CAMOPSUF and urea formaldehyde wood composites, respectively, at a density level of $0.8 \mathrm{gcm}^{-3}$. At lower relative humidity, moisture was released from the wood composites, while creating hydrogen bonds, which resulted in the decrement of thickness. Meanwhile, increasing the relative humidity leads to the penetration of more moisture into the particleboard, causing hydrogen bonds to break and residual stress from the hot-pressing process to be released, resulting in a boost in thickness.

\section{Mechanical properties}

The bending test yielded the modulus of rupture (MOR) and the modulus of elasticity (MOE) of the prepared particleboard. The modulus of rupture measures the strength of the samples, while the modulus of elasticity indicates the stiffness of the sample. In general, all the samples showed higher MOR and MOE, as the density increased. The higher compaction ratio of the higher density panels resulted in wood composites with higher strength. The addition of urea formaldehyde to the wood composites has improved their mechanical strength. MOR increased from $12.35 \mathrm{Nmm}^{-2}$ to $16.27 \mathrm{Nmm}^{-2}$ and $25.54 \mathrm{Nmm}^{-2}$, while MOE rose from 3046.80 $\mathrm{Nmm}^{-2}$ to $3784.99 \mathrm{Nmm}^{-2}$ and $5039.47 \mathrm{Nmm}^{-2}$ for CAMOPS, CAMOPSUF and urea formaldehyde wood composites, respectively. Comparisons were made to investigate the improvement of mechanical properties due to the use of CAMOPS and CAMOPSUF binders. The MOE values in this study are significantly higher compared to those reported in similar studies by Sekaluvu et al. ${ }^{32}$ Chotikhun and Hiziroglu ${ }^{33}$ and Moubarik et al. ${ }^{34}$ as shown in Table 2. The MOR results obtained for the wood composites made at 0.80 $\mathrm{g} / \mathrm{cm}^{3}$ density are in agreement with those found in previous studies, ranging from $11.86 \mathrm{Nmm}^{-2}$ to $12.35 \mathrm{Nmm}^{-2}$. With regard to internal bonding strength, the CAMOPS wood composite shows a significantly higher value than that of its most similar competitor, which is the epichlorohydrin modified oil palm starch wood composite, with a difference of $0.34 \mathrm{Nmm}^{-2}$.

The addition of urea formaldehyde has also lowered the crystallinity of the samples, thus increasing their mechanical properties, as discussed in the X-ray diffraction analysis. Internal bonding test also showed a similar trend, where the addition of urea formaldehyde increased the internal bonding strength of the wood composites. All the wood composite samples, except for CAMOPS at $0.60 \mathrm{gcm}^{-3}$ density level, passed the Japanese Industrial Standard, which requires $0.80 \mathrm{Nmm}^{-2}$ and 2000 $\mathrm{Nmm}^{-2}$ for MOR and MOE, respectively. Without exception, all of the samples passed the Japanese Industrial Standard requirement of $0.15 \mathrm{Nmm}^{-2}$ for internal bonding strength.

\section{Fungal resistance}

The wood composites were inoculated with four types of wood decaying fungi, namely Schizophyllum commune, Pycnoporus sanguineus, Formitopsis palustris and Trametes versicolor. Schizophyllum commune, Pycnoporus sanguineus and Trametes versicolor are white-rot fungi, while Formitopsis palustris is a brown-rot fungus. Brown-rot fungi are usually associated with softwood attack, without the involvement of lignin-degrading enzymes. Meanwhile, white-rot fungi mostly attack hardwood, with the participation of both cellulolytic and lignindegrading enzymes. ${ }^{35}$ 
Table 3

Fungal degradation test of manufactured wood composites

\begin{tabular}{lccccc}
\hline Panel type & $\begin{array}{c}\text { Target density, } \\
\mathrm{g} / \mathrm{cm}^{3}\end{array}$ & $\begin{array}{c}\text { Schizophyllum } \\
\text { commune, \% }\end{array}$ & $\begin{array}{c}\text { Pycnoporus } \\
\text { sanguineus, } \%\end{array}$ & $\begin{array}{c}\text { Formitopsis } \\
\text { palustris, } \%\end{array}$ & $\begin{array}{c}\text { Trametes } \\
\text { versicolor, \% }\end{array}$ \\
\hline \multirow{2}{*}{ CAMOPS } & 0.60 & $3.19 \pm 1.49 \mathrm{a}$ & $17.86 \pm 0.67 \mathrm{a}$ & $10.15 \pm 0.68 \mathrm{a}$ & $32.96 \pm 0.68 \mathrm{a}$ \\
& 0.70 & $13.20 \pm 0.96 \mathrm{~b}$ & $14.00 \pm 0.44 \mathrm{~b}$ & $5.45 \pm 1.24 \mathrm{~b}$ & $32.93 \pm 1.76 \mathrm{a}$ \\
& 0.80 & $17.19 \pm 1.26 \mathrm{c}$ & $15.45 \pm 2.09 \mathrm{~b}$ & $11.66 \pm 0.90 \mathrm{c}$ & $35.99 \pm 1.10 \mathrm{~b}$ \\
\hline \multirow{2}{*}{ CAMOPSUF } & 0.60 & $12.11 \pm 0.96 \mathrm{a}$ & $39.19 \pm 2.12 \mathrm{a}$ & $7.96 \pm 1.26 \mathrm{a}$ & $27.04 \pm 1.46 \mathrm{a}$ \\
& 0.70 & $20.06 \pm 1.05 \mathrm{~b}$ & $26.68 \pm 1.21 \mathrm{~b}$ & $3.44 \pm 0.35 \mathrm{~b}$ & $23.46 \pm 1.42 \mathrm{~b}$ \\
\multirow{2}{*}{ Urea } & 0.80 & $14.26 \pm 0.77 \mathrm{c}$ & $27.79 \pm 0.88 \mathrm{~b}$ & $8.51 \pm 0.88 \mathrm{a}$ & $23.65 \pm 0.54 \mathrm{~b}$ \\
formaldehyde & 0.60 & $9.86 \pm 0.34 \mathrm{a}$ & $16.57 \pm 1.85 \mathrm{a}$ & $12.57 \pm 0.48 \mathrm{a}$ & $8.34 \pm 1.01 \mathrm{a}$ \\
& 0.70 & $6.72 \pm 1.60 \mathrm{~b}$ & $8.63 \pm 1.00 \mathrm{~b}$ & $6.21 \pm 1.34 \mathrm{~b}$ & $13.84 \pm 1.45 \mathrm{~b}$ \\
& 0.80 & $8.98 \pm 1.46 \mathrm{a}$ & $13.19 \pm 1.24 \mathrm{c}$ & $3.88 \pm 0.66 \mathrm{c}$ & $12.94 \pm 1.39 \mathrm{~b}$ \\
\hline
\end{tabular}

*different letter in the same column and for the same type of binder shows significant difference at a value of 0.05

It has been reported previously that the $\mathrm{C}-\mathrm{N}$ groups, as detected by FT-IR analysis, have an antioxidant ability, which carries biocidal properties against certain fungal and bacterial species. ${ }^{36}$ However, no significant difference between white-rot and brown-rot attack was observed in this study. A different geometry of the particles has determined a different decaying activity of the fungi, compared to that in the case of solid wood. No relation between the binder and the degradation behaviour of the particleboard, caused by Schizophyllum commune, Pycnoporus sanguineus and Formitopsis palustris, could be established. However, upon adding urea formaldehyde, the decaying action of Trametes versicolor was reduced from $33.96 \%$, to $24.72 \%$ and $11.71 \%$ for CAMOPS, CAMOPSUF and urea formadehyde wood composites, respectively. White-rot fungi are usually more resistant to chemicals. However, this does not apply in all the cases, suggesting that susceptibility to decay is dependent on other factors as well, such as environmental moisture and physical properties of the wood composites, rather than solely the fungal species and resin type. ${ }^{37}$

\section{CONCLUSION}

Results showed that citric acid modified oil palm starch (CAMOPS) used as binder for wood composites can reduce the crystallinity of the fibers, thus, increasing the thermal stability of the composites, while slightly declined the mechanical strength, as shown by the TGA and bending analyses. Thickness swelling of the composites after water immersion has been improved significantly after the addition of urea formaldehyde, from $100.96 \%$ to $79.37 \%$ and $48.52 \%$ for CAMOPS, CAMOPSUF and urea formaldehyde wood composites, respectively. A minimum of $0.70 \mathrm{gcm}^{-3}$ density level is required for all the prepared wood composites to achieve the mechanical strength required by Japanese Industrial Standards. Therefore, citric acid modified oil palm starch can be utilized as an alternative, environmentally friendly binder for manufacturing wood composites with exceptional properties.

ACKNOWLEDGMENT: The authors express their gratitude to the Ministry of Higher Education Malaysia for Research Acculturation Grant

(R/RAGS/A08.00/01046A/002/2015/000302)

awarded to Mohd Hazim Mohamad Amini and to Universiti Sains Malaysia for the Research University Grant (1001/PTEKIND/815066) given to Rokiah Hashim. The authors also acknowledge the Heveaboard (Malaysia) Sdn. Bhd. for providing the raw materials for composite making.

\section{REFERENCES}

1 C. Nagiah and R. Azmi, J. Oil Palm Res., 3, 114 (2012),

https://www.jopeh.com.my/index.php/jopecommon/art icle/view/58

2 Y. Basiron, Eur. J. Lipid Sci. Tech., 109, 289 (2007), https://doi.org/10.1002/ejlt.200600223

T. M. I. Mahlia, M. Z. Abdulmuin, T. M. I. Alamsyah and D. Mukhlishien, Energ. Convers. Manag., $\quad 42, \quad 2109 \quad$ (2001), https://doi.org/10.1016/S0196-8904(00)00166-7

4 I. C. Yadav and N. L. Devi, in "Reference Module in Earth Systems and Environmental Sciences", edited by S. A. Elias, D. H. M. Alderton, V. Bliznak, J. K. Cochran, D. A. DellaSala et al., Elsevier Inc., 2018, 
pp. 1-7, https://doi.org/10.1016/B978-0-12-4095489.11022-X

5 M. A. Mohd. Noor, A. M. Dos Mohd, M. N. Islam and N. A. Mehat, Starch-Starke, 51, 293 (1999), https://doi.org/10.1002/(SICI)1521-

379X(199909)51:8/9\%3C293::AID-

STAR293\%3E3.0.CO;2-F

6 Y. Tomimura, Jarq-Jpn. Agr. Res. Q., 25, 283 (1992),

https://www.jircas.go.jp/sites/default/files/publication/j arq/25-4-283-288_0.pdf

7 M. Hadei, P. K. Hopke, M. Rafiee, N. Rastkari, M. Yarahmadi et al., Environ. Sci. Pollut. Res. Int., 25, 27423 (2018), https://doi.org/10.1007/s11356-0182794-4

8 N. S. Sulaiman, R. Hashim, M. H. M. Amini, O. Sulaiman and S. Hiziroglu, BioResources, 8, 283 (2013), https://doi.org/10.15376/biores.8.1.283-301

9 X. Ma, P. R. Chang, J. Yu and M. Stumborg, Carbohyd. Polym., $\quad$ 75, 1 (2009), https://doi.org/10.1016/j.carbpol.2008.05.020

10 N. S. Sulaiman, R. Hashim, S. Hiziroglu, M. H. M. Amini, O. Sulaiman et al., Cellulose Chem. Technol., 50, $329 \quad$ (2016), http://www.cellulosechemtechnol.ro/pdf/CCT2(2016)/ p.329-338.pdf

11 A. Moubarik, A. Pizzi, A. Allal, F. Charrier and B. Charrier, Ind. Crop. Prod., 30, 188 (2009), https://doi.org/10.1016/j.indcrop.2009.03.005

12 M. H. M. Amini, R. Hashim, S. Hiziroglu, N. S. Sulaiman and O. Sulaiman, Compos. Part B-Eng., 50, 259

https://doi.org/10.1016/j.compositesb.2013.02.020

13 I. Paetau, C.-Z. Chen and J.-L. Jane, Ind. Eng. Chem. Res., 33, 1821 (1994), https://doi.org/10.1021/ie00031a023

14 V. T. Karathanos, J. Food Eng., 39, 337 (1999), https://doi.org/10.1016/S0260-8774(98)00132-0

15 N. Reddy and Y. Yang, Food Chem., 118, 702 (2010),

https://doi.org/10.1016/j.foodchem.2009.05.050

16 M. H. M. Amini, R. Hashim, N. S. Sulaiman, O. Sulaiman, S. F. Sulaiman et al., Appl. Mech. Mater., 755, $1040 \quad$ (2015), https://doi.org/10.4028/www.scientific.net/AMM.754755.1040

17 J. H. Muyonga, C. G. B. Cole and K. G. Duodu, Food Chem., 86, $325 \quad$ (2004), https://doi.org/10.1016/j.foodchem.2003.09.038

18 D. Hermawan, T. Hata, S. Kawai, W. Nagadomi and Y. Kuroki, J. Wood Sci., 48, 20 (2002), https://doi.org/10.1007/BF00766233

19 Japanese Standards Association, Japanese Industrial Standard Committee, Standard particleboard (A 5908), Tokyo, Japan, 2003, https://www.jsa.or.jp/en/

20 British Standards, Standard fungal resistance of panel products made of or containing materials of organic origin (BS 1982-3), London, United Kingdom,
British Standards Institution, 1990, https://www.bsigroup.com/

21 K. Umemura, O. Sugihara and S. Kawai, J. Wood Sci., 61, 40 (2015), https://doi.org/10.1007/s10086014-1437-8

22 A. P. Singh, V. Causin, A. Nuryawan and B.-D. Park, Eur. Polym. J., 56, 185 (2014), http://dx.doi.org/10.1016/j.eurpolymj.2014.04.014

23 I. Azman, S. A. Mutalib, S. F. M. Yusoff, S. Fazry, A. Noordin et al., J. Bioact. Compat. Polym., 31, 42 (2016), https://doi.org/10.1177/0883911515597704

24 N. P. Cheremisinoff "Polymer Characterization Laboratory Techniques and Analysis", William Andrew Inc., 1996, pp. 1-262, https://doi.org/10.1016/B978-081551403-9.50004-2

25 S. F. Ibrahim, E. S. El-Amoudy and K. E. Shady, Int. J. Chem., $\quad \mathbf{3}, 40 \quad$ (2011), www.ccsenet.org/journal/index.php/ijc/article/downloa d/5417/7768

26 S. A. Osemeahon, O. N. Maitera, A. J. Hotton and B. J. Dimas, J. Environ. Chem. Ecotoxicol., 5, 181 (2013), https://doi.org/10.5897/JTEHS2013.0264

27 L. V. A. Gurgel, K. Marabezi, L. A. Ramos and A. A. D. S. Curvelo, Ind. Crop. Prod., 36, 560 (2012), https://doi.org/10.1016/j.indcrop.2011.11.009

28 U.-J. Kim, S. H. Eom and M. Wada, Polym. Degrad. Stabil., 95, $778 \quad$ (2010), https://doi.org/10.1016/j.polymdegradstab.2010.02.009 29 R. Liao, J. Xu and K. Umemura, BioResources, 11, 2174 (2016), https://doi.org/10.15376/biores.11.1.2174-2185

30 M. Ghofrani, A. Ashori and R. Mehrabi, Polym. Test., $\quad 60, \quad 153 \quad$ (2017), https://doi.org/10.1016/j.polymertesting.2017.03.028

31 R. Hashim, M. H. M. Amini, O. Sulaiman, S. Hiziroglu, F. Kawamura et al., J. Compos. Mater., 45, 901 (2011), https://doi.org/10.1177/0021998310377941

32 L. Sekaluvu, P. Tumutegyereize and N. Kiggundu, Waste Biomass Valor., 5, 27 (2014), https://doi.org/10.1007/s12649-013-9228-9

33 A. Chotikhun and S. Hiziroglu, J. Nat. Fiber., 14, 541 (2017) https://doi.org/10.1080/15440478.2016.1240642

34 A. Moubarik, H. R. Mansouri, A. Pizzi, A. Allal, F. Charrier et al., Compos. Part B-Eng., 44, 48 (2013), https://doi.org/10.1016/j.compositesb.2012.07.041

35 B. Goodell, Y. Qian and J. Jellison, in "Development of Commercial Wood Preservatives", edited by T. P. Schultz, H. Militz, M. H. Freeman, B. Goodell and D. D. Nicholas, American Chemical Society, 2008, pp. 9-31, https://doi.org/10.1021/bk2008-0982.ch002

36 A. M. Lazim, I. Azman, S. F. M. Yusoff, N. I. Hassan, S. Fazry et al., Prog. Org. Coat., 99, 182 (2016), https://doi.org/10.1016/j.porgcoat.2016.05.022 37 S. F. Curling and R. J. Murphy, Wood Sci. Technol., 33, $\quad 245$ (1999), https://doi.org/10.1007/s002260050113 